Journal of Education and Vocational Research

Vol. 2, No. 3, pp. 86-92, Sep 2011 (ISSN 2221-2590)

\title{
The Contribution of Entrepreneurship Education Course in Enhancing Management Skills of Informal Entrepreneurs
}

\author{
Samuel Muchiri Mwangi \\ Gusii Institute of Technology, Kisii, Kenya \\ smwangi83@yahoo.com
}

\begin{abstract}
The study was conducted to investigate the contribution of entrepreneurship education in technical training colleges in enhancing management skills of informal sector entrepreneurs in Kenya. A case study of informal sector operators in Nairobi was conducted. Qualitative data was collected using in-depth interviews and observations. The data was analyzed using the grounded theory. Findings of the study showed that the informal sector operators used skills they gained in entrepreneurship education in technical training colleges to gain access to the informal sector industry and to manage their business. Those with higher training in entrepreneurship education tended to excel in their operations. A closer look showed that there was still a need for further training of management skills to better their activities. The recommendations were that secondary schools in Kenya should include entrepreneurship in secondary education system curriculum so as to help the school leavers who fail to join tertiary education and end up in the informal sector.
\end{abstract}

Key words: Entrepreneurship education, technical training colleges, management skills, informal sector entrepreneurs, Kenya.

\section{Introduction}

Poverty level characterized by a large number of unemployed youths is generally high in sub-Sahara Africa. In the $21^{\text {st }}$ century we are living in, unemployment of youths is one of the major challenges. In Kenya there are thousands of technical training college graduates who pass their certificate or diploma examinations but due to the prevailing unemployment crisis they cannot find employment. As a coping mechanism, the informal sector has turned out to be one alternative. Graduates from technical training colleges end up joining informal sectors to start small businesses and become entrepreneurs so as to support themselves and their families financially. So as to develop entrepreneurial culture to all graduates of technical training colleges, entrepreneurship education is given in different countries including Kenya in formal, informal and nonformal way through Technical, Industrial and Vocational Education and Training (TIVET) colleges and institutes of science and technology. Entrepreneurship education is designed in order to support graduates, existing and potential entrepreneurs to create and run their own business rather than expecting employment from government, private or non-governmental organizations (NGOs).

Entrepreneurship education in Kenya is targeted to produce entrepreneurs who are able to create own jobs rather than seeking employment in any organization. That is why entrepreneurship training is incorporated in TIVET college curriculum. However, Graduates who are involved in entrepreneurial activities in the informal sector face many challenges. These include lack of knowledge of business accounting, administration and management. Their success in business in the informal sector greatly depends on entrepreneurial management skills they gained in college though entrepreneurship education subject. The aim of this study, therefore, was to investigate the contribution of entrepreneurship education in technical training colleges in enhancing management skills of informal sector entrepreneurs in Kenya. The objectives of this study were. To identify entrepreneurship education involvement in the informal sector. Investigate the contribution of entrepreneurship education in technical training colleges in enhancing management skills of informal sector entrepreneurs. Recommend ways on how entrepreneurship education can be suited in ensuring good management skills of in technical training colleges' graduates involved in the informal sector. 


\section{Literature Review}

Definition and objectives of entrepreneurship education: Sexton and Smilor (1997) define entrepreneurship education as a formal structured instruction that conveys entrepreneurial knowledge and develops in students, focused awareness relating to opportunity, recognition and the creation of new ventures. Mauchi et al (2011) sited in Jones and English (2004) the definition of entrepreneurship education as the process of providing individuals with the ability to recognize commercial opportunities and the knowledge, skills and attitudes to act on them. Therefore, entrepreneurship education can be seen as process of imparting learners with entrepreneurial knowledge, skills and attitudes through a formal structured instruction. A formal structured instruction is usually guided by well defined aims, goals and objectives of a specific program. According to Colton (1990) entrepreneurship education and training programmers are aimed directly at stimulating entrepreneurship which may be defined as independent small business ownership or the development of opportunity-seeking managers within companies.

The major objectives of enterprise education are to develop enterprising people and inculcate an attitude of self-reliance using appropriate learning processes. The following are the most commonly cited objectives of entrepreneurship education and training programmed: to acquire knowledge germane to entrepreneurship; to acquire skills in the use of techniques, in the analysis of business situations, and in the synthesis of action plans; to identify and stimulate entrepreneurial drive, talent and skills; to undo the risk-adverse bias of many analytical techniques; to develop empathy and support for all unique aspects of entrepreneurship; to devise attitudes towards change; to encourage new start-ups and other entrepreneurial ventures. (Thomas and Barra , 1994). It can be seen that these objectives underscore the fact that entrepreneurship education should reflect carefully on acquisition of business skills and ways of enhancing the probability of success. The objectives of entrepreneurship education are mainly focused on starting a business and subsequent sustainability of the business. Thus, entrepreneurs are characterized by innovative behavior and employ strategic skills and management practices with the aim of making a profit and growth.

The role of Entrepreneurship Education offered in technical and vocational training institutions in Acquisition of Business Skills: The introduction of entrepreneurship education in technical training colleges in Kenya represents an innovation in tertiary education institutions that is relevant to the informal sector. According to Haan (2006) entrepreneurship education programmers helps develop attitudes favorable to starting one's own business and provide knowledge and skills for running a business, e.g. business law, accounting and bookkeeping, credit and finance, and marketing. Skills development encompasses a broad range of core skills (entrepreneurial, communication, financial, management and leadership) so that individuals are equipped for productive activities and employment opportunities (wage employment, selfemployment and income generation activities).

Previous research on the role of Entrepreneurship Education offered in various tertiary education institutions in development on formal and informal sector show that graduates with Entrepreneurship Education and training seem to start and run a business with ease. Conversely, many studies that have been conducted recently have showed that entrepreneurship education does play a significant role to cultivating entrepreneurship spirit among graduates. Farstad (2002) researched on entrepreneurship education programmers offered in secondary and tertiary education institutions in Kenya, Botswana, and Uganda. He found that in a comparison of graduates of general secondary education programmers and those from technical and vocational education programmers, the latter group was more likely to start businesses within a few years of graduation. This is because graduates from technical and vocational education were equipped with entrepreneurship skills through Entrepreneurship Education and Business Planning courses they were taught in college. The technical education provided a skill that was then honed on the job with an apprenticeship and wage employment before setting out to start a new business.

A survey done by the Entrepreneurship Development Institute, India (EDII) in 2003 shows that young people are afraid to start their own business because they are not confident, not capable, and lack knowledge in starting a business (Zhang, 2006). Many people have the opportunity to change jobs or become an entrepreneur if they are properly trained. The students in India are not satisfied with the "hands-on" support of their university in the founding process (Zhang, 2006). Moreover, the entrepreneurship courses are 
similar to the general business courses. The findings of a survey on business owners in India suggest that management education is not an important driver of entrepreneurial attitudes (Gupta, 2004). The survey showed that there is a demand for entrepreneurship education programs specifically designed to expand students' knowledge and experience in entrepreneurship. The contents and teaching methods have to be differentiated between entrepreneurship and traditional business courses. Based on a study done by Lars and Moen (1997) it is shown that as compared to other students, those who have taken entrepreneurship education have revealed greater interest to become entrepreneurs and these students act more entrepreneurial than other students in taking up the challenge to start up a new business. Thus, it is suggested that although it may not be possible to develop entrepreneurship from education exclusively, to certain extent, education does have an effect to alter and contribute to the formation of entrepreneurship.

School and education system play a critical role in identifying and shaping entrepreneurial traits (Ibrahim and Soufani, 2002). Other studies have pointed out that entrepreneurship education, especially education that provides technological training is crucial to enhance entrepreneurs' innovation skills in an increasingly challenging environment woven into the model is the local learning environment and the macro environment (Clarke, 1990). Thus, entrepreneurship education has encouraged schools to think outside traditional patterns of pedagogy and classroom instruction. Periods of mandatory work placement have been introduced along with compulsory development of a business plan subject to examination and grading. This subject is aimed at imparting graduates with entrepreneurial, communication, financial, management and leadership skills with are essential to entrepreneurs. The researcher conceptually assumes that with the 'right' entrepreneurship education, the informal sector operators would develop and most of the operators' problems on management skills would be alleviated. Against this background, the study aimed at determining the contribution of entrepreneurship education in public technical training colleges in enhancing management skills of informal sector entrepreneurs in Kenya.

\section{Research Methodology}

This research was conducted using case study approach. A case study of informal sector entrepreneurs in Nairobi region was conducted. The case study was chosen as it is more focused in yielding the type of data anticipated. A case study allows a researcher to explore in depth a program, an event; an activity and researchers collect detailed information using variety of data collection procedures (Creswel, 2003). The case study was ideal in that, relevant data was collected using one group as the idea of comparison was deemed not necessary. The population of the study consisted of all technical college graduates working in informal sector in Nairobi region. The Nairobi region was chosen because it has a high number of informal sector operators compared to other regions in Kenya. The population was selected because they are better placed to investigate the contribution of entrepreneurship education in public technical training colleges in enhancing management skills of informal sector entrepreneurs in the Kenya informal sector. A sample of thirty participants was randomly selected from the population. There are many informal sector establishments in Nairobi area. However, the researcher concentrated on only four informal sector centres (Gikomba, Kamkunji, Jericho, and Ziwani) which are the biggest and most popular and populous. This gave the advantage that both mature and young operators were interviewed.

Materials: In order to triangulate findings, multiple strategies were employed for data collection. The study employed a combination of interviews and participant observation in collecting data. A detailed interview schedule was developed to guide the data collection. Participant observation was the other data gathering strategy used. Items and points observed were carefully screened and then listed. An observation checklist was then constructed to guide the observer. Observation of the operatives at work also helped in validation and cross checking of the issues discussed in the interviews.

Validity of the research instruments: Hair et al (1998) suggests that the best way in which to ensure content validity is to subject the instrument to judgmental validation by experts in the area. In this study the experts were two lecturers at Gusii Institute of Technology from Research and Development department who examined them and provided valuable suggestions and comments, which were used as basis to modify the research items to make them adaptable to the study. Based on the feedback offered by those experts who examined the interview schedule, the terminologies, questions, objectives and content of the interview 
schedule was modified to either include or exclude some items. This is due to the fact that some items could have been included that captures irrelevant data or some items have been excluded that would have helped the researcher to capture some important information regarding the study. Their feedback, both positive and negative, shaped the final version of the interview schedule.

Procedure: The researcher made many visits to the informal sector business site, to familiarize himself with the operations and people at the Nairobi informal sector centers. This is important because people tend to resist any new person who would want to interview them. Talking to individuals began as soon as rapport was established. Many visits were necessary because of the conversational techniques used. After interviewing, the researcher watched the operations to cross-validate the interviews. A report was compiled immediately after the interview. It was necessary to revisit some interviewees to get them to clarify certain issues which would be missing when writing the draft report. Data collected from the interviews was analyzed by qualitative means. Meanings of the discussions were drawn, coded and categorized into themes using the grounded theory (Strauss and Corbin, 1990). The responses from the interviews were analyzed into concepts and related concepts were categorized into families. Themes were then deduced from the code families. Themes from the data then told the story. Some data was quantified to give clearer meaning to the story. Values and meanings were attached to the observations. Cross validation between what was discussed and observed was done. This was done by changing and observing what was discussed.

\section{Results and Discussion}

Results: The results showed that the operatives in Nairobi informal sector were characterized by low levels of secondary school passes or had only attained primary education. Their ages ranged from twenty to forty five years. The sector also had many school drop-outs. Forces that made people join the home industry were varied. Notably, some joined as a result of job losses in the formal sector as a result of lack of employment in the formal sector. Others were drawn by the successes of those already operating in the home industry. Family influence also brought some to the informal sector industry. Family tradition in craft still extended to junior family members. These came to Nairobi informal sectors when the Nairobi Municipality designated these areas for craft and trade in the informal sector. Of importance was the fact that the operatives indicated that they were not willing to go out to seek work in the formal sector any more because they felt that what they were now doing was important and that it paid well besides the fact that they were not formally qualified. The operatives enjoyed the fluidness, flexibility and diversity of the products and trade at Nairobi informal sector. The independence they enjoyed was better than the constrained atmosphere of the formal sector they said.

Because of their low level of formal education most operatives interviewed had, they were not formally trained in the jobs they were doing. The entrepreneurship skills they engaged in were mostly acquired through on-the-job training. They gained skills by acting as assistants to those who were experienced or through association with the trade over a long period of time. Some had formal training from companies they worked for before they were retrenched. The spaces the operatives worked from were owned by the municipality owned and they lease the stands. Some of the working system is feudal. The original owner subleased to tenants who paid every month for their work places. Some operatives shared stands and contributed equally at the end of the month. In some cases the original land-lord still operated their stands. When asked what they (operatives) thought about how their entrepreneurship education was helping their operations, they said whatever education or literacy they had been adequate. The following is an extract from an interview with an operative:

Q. What kind of business do you do?

A. I repair vehicles, assemble vehicle parts and sometimes sell vehicle spare parts.

Q. Do you find the entrepreneurship education you have of any use to what you are doing?

A. I did a certificate course in automotive engineering level but did not get enough passes for me to get into formal employment. In college we were taught how to start and run a small business. That is what helped me most and I decided to start my own business. 
Q. Has entrepreneurship education you got in school relevant to your business?

A. Yes, in so many ways. It helps me with skills on how to plan my daily work, how to identify business opportunities and how to monitor and manage the growth of my business.

Q. How has entrepreneurship education help you to manage your business?

A. In a way, entrepreneurship education helps me to know how to budget and save some money because I want to expand my business.

Q. What management skills did entrepreneurship education instill in you?

A: Managing my finance by saving in a bank and budgeting for my daily needs in the business. I also make sure that I keep record of all expenses incurred during the day to monitor my financial expenditure.

Q. What level of entrepreneurship education would one require to manage a business like your?

A. Its difficult to say what level because I have certificate and feel adequate, my friends here might not have entrepreneurship education but can manage their business well. However they have difficulties in making management records like profit and loss account and budgeting. Some skills you learn as you observe but obviously entrepreneurship education makes you a better manager.

Q. According to you, what does good business management entail?

A. Well, it may involve checking how much you spend, save, making business grow and knowing your customers well. It may also entail planning on expanding business and bringing more customers.

Q. Do you use entrepreneurship education books here?

A. Yes, I refer to some materials especially how to make a budget and how to calculate profits and returns. This is because a successful entrepreneur has to be updated all the time or refer to the books when stuck.

Q. Do you think young people have a negative attitude towards informal sector employment?

A. People want to go and get work elsewhere but when it fails, they want to come here. Now it is full too. But those coming from the country without any entrepreneurial skills come here too and say they can do any job they can get. Some get their relatives or friends.

Q. Which education do you find most suitable for the activities you do?

A. A good hand in practical work is necessary but entrepreneurship education is necessary to run a successful business.

Q. Do you mean 'O' level with entrepreneurship subjects?

A. Yes I think so. Look, if one is retrenched without any practical entrepreneurship skills what will you survive on? I could find something to do because I am skilled. I am surviving very well. Entrepreneurship education is very important I assure you.

The Nairobi informal sector operators said their businesses were mostly manufacturing or repairing and marketing which did not demand high levels of education. Their ' $O$ ' level or primary education seemed adequate for their purposes. However, they expressed high consideration for anyone among them with entrepreneurship education. The study also found that those involved in the informal sector at Nairobi informal sector centers had qualifications ranging from primary to tertiary education. School drop-outs were also found there. The operation level of the informal sector provides simple but basic and necessary everyday needs of the local artifacts and services to meet the community. This being the case, the entrepreneurship educational qualifications necessary to enable the manufacture and provision of services maybe somewhat low. The low educational demands of the sector should not necessarily mean total absence of entrepreneurship education. Those with primary education seemed to do well in the sector. The output and quality of goods and services tended to improve with entrepreneurship education.

Discussion: The study investigated the contribution of entrepreneurship education in technical training colleges in enhancing management skills of informal sector entrepreneurs in Kenya. It identified and confirmed the idea that entrepreneurship education has a lot of potential in the TVET graduates who end up 
working in the informal sector. Those with technical education certificates were regarded as better skilled in entrepreneurship and that they were quick to learn new tasks and improved business capabilities. Such education offers the only viable alternative in successive business development. The operatives also yearned for more entrepreneurship education if given a chance. They longed for training in entrepreneurship training skills that were in line with their trade and the present business technology.

There was also desire to be trained in business management. Observations made tended to confirm that services offered depended on the craftiness of the person, customers' specifications and that the clients' money demanded better products and quality of the products. Operatives with entrepreneurship education seemed more organized in their work compared to those with lower qualifications. This implies that entrepreneurship education in technical and vocational education and training provides a sound base for both the formal and informal sector manpower needs of the economy, particularly in the developing world. From the results, it is clear that the operatives at Nairobi informal sector centers indicated that even primary education was adequate for them. The main issue was not education levels but the type of education required. Those with entrepreneurship education were highly regarded and seemed to do well. Technical and vocational education contributed positively to the operation of the informal sector development.

Many operatives thought entrepreneurship education gave them better chances of quickly grasping the problems that they confronted in their businesses. Those with entrepreneurship education seemed to have better business management skills. The group which was retrenched from the formal sector but was operating from Nairobi informal sector centers, ranged from those without high educational qualifications to those who had on-the-job training experience. Again, entrepreneurship education had helped those retrenched from formal industries to join the informal sector easily. There was a call by almost all operatives that there was a dire need to expand and improve both technical and trade skills. They felt that with a good entrepreneurship education base, they could expand and improve their operations. Some indicated the need for business training. If the operatives were granted entrepreneurship skills, then the image and outlook of the informal sector would improve.

\section{Conclusions and Recommendations}

In conclusion, there is definitely a need for an educational intervention if the informal sector is to develop. The members in the informal sector seem to appreciate the contribution of entrepreneurship education in informal sector development. The study has shown that entrepreneurship education contributes immensely to the everyday operations of the informal sector. Those with entrepreneurship education tended to do better than those without or with general education. One can recommend the strengthening of technical and vocational education in schools, mostly at secondary level, by introducing entrepreneurship education so as to help those who drop out of school for one reason or the other or for those who are unable to proceed to tertiary institution. This would help in that, those who drop out of the system would benefit from whatever entrepreneurship education they had acquired. Those who finish school could then be involved in selfemployment or join the informal sector like Nairobi informal sector centers, if they failed to secure employment in industry. These school leavers could utilize the entrepreneurship education acquired from schools, to find something worthwhile to do. They could start joint ventures as cooperatives or go solo using whatever skills they learnt at school. Many retrenches from the formal sector bring entrepreneurship skills learnt in their jobs to the informal sectors. This proves that technical and vocational skills are essential for the survival of the school leaver and the retrenched.

The study recommends that schools teach and train skills which are directly usable in the informal sector. The study also recommends entrepreneurship education training programmers for those already working in the informal sector. A needs analysis research should be carried out to determine the exact educational requirements useful in the informal sector. There is also a need to carry out a research to assess the productivity and performance of the operatives at Nairobi informal sector centers in comparison to that of school leavers, drop-outs and those from the formal sector. This would then facilitate a base for drawing up programmers of action. Furnishing management skills is required to improve productivity in the informal sector. 


\section{References}

Clarke, T. (1990). Review of the Status and Availability in Canadian Colleges and Universities of Courses or Programs Dealing with the Commercialization and Adoption of Science and Technology. Report for Industry, Science and Technology Canada, Ottawa.

Colton, T. (1990). Enterprise Education Experience. A Manual for School Based Inservice Training, CA SDEC.

Creswel, J. (2003). Research Design: Qualitative, Quantitative, and Mixed Methods Approaches, 2nd Edn. Sage Publications Ltd, UK.

Farstad, H. (2002). Integrated Entrepreneurship Education in Botswana, Uganda, and Kenya: Final Report. National Institute of Technology, Oslo.

Gupta, A. (2004). Starting up isn't easy. Today Business.

Haan, C. (2006). Training for work in the informal micro-enterprise sector: fresh evidence from Sub-Sahara Africa. Dordrecht, Netherlands: Springer.

Hair, J. F., Anderson, R. E., Tatham R. L. \& Black, W. C. (1998). Multivariate Data Analysis 5th Edition, California: Prentice-Hall International Inc.

Ibrahim, A. \& Soufani, K. (2002). Entrepreneurship education and training in Canada: A critical assessment. Education + Training, 44 (8), 421-430.

Jones, C. \& English, J. (2004). A contemporary approach to entrepreneurship education. Educ. Training, 46(8), 416-423.

Lars, K. \& Moen, O. (1997). Entrepreneurship among business graduates: does a major in entrepreneurship make a difference? Journal of European Industrial Training, 21(4), 154-160.

Mauchi, N. F., Karambakuwa, T. R., Gopo, N. R., Kosmas, N., Mangwende, S. \& Gombarume, B. F. (2011). Entrepreneurship education lessons: a case of Zimbabwean tertiary education institutions. Educational Research, 2(7), 1306-1311.

Sexton, D. \& Bowman, N. (1984). Entrepreneurship Education Suggestions for Increasing Effectiveness. Journal of Small Business Management, 22 (2), 18-25.

Sexton, D. \& Smilor, R. (1997). Entrepreneurship. Upstart Publishing Company. Chicago Illinois.

Strauss, A. \& Corbin, J. (1990). Basics of Qualitative Research: Theory of Procedures and Techniques Grounded. London: SAGE Publishers.

Thomas, N. \& Barra, O. (1994). Entrepreneurship Education and Training Programmes: A Review and Evaluation-Part 1. Journal of European Industrial Training, 18(8), 3-12.

Zhang, L. (2006). Entrepreneurship Education within India's Higher Education System. Asian Scholar, 1(2), 112. 